\title{
Host and Nonhost Resistance in Medicago-Colletotrichum Interactions
}

Valérie Jaulneau,,$^{1,2,3}$ Marc Cazaux, ${ }^{1,2}$ Joanne Wong Sak Hoi, ${ }^{1,2}$ Sylvie Fournier,,$^{1,2}$
Marie-Thérèse Esquerré-Tugayé,, ${ }^{1,2}$ Christophe Jacquet, ${ }^{1,2}$ and Bernard Dumas,

${ }^{1}$ Université de Toulouse, UPS, and ${ }^{2}$ CNRS, Surfaces Cellulaires et Signalisation chez les Végétaux, 24 chemin de Borde Rouge, BP42617, Auzeville, F-31326, Castanet-Tolosan, France; ${ }^{3}$ Groupe Roullier, Zone Industrielle-BP 72, F22260, Pontrieux, France

Submitted 4 December 2009. Accepted 8 May 2010.

\begin{abstract}
Medicago truncatula lines resistant (A17) or susceptible (F83005.5) to the alfalfa pathogen Colletotrichum trifolii were used to compare defense reactions induced upon inoculation with $C$. trifolii or with the nonadapted pathogens C. lindemuthianum and C. higginsianum. Nonadapted Colletotrichum spp. induced a hypersensitive response (HR)like reaction similar to the one induced during the hostincompatible interaction. Molecular analyses indicated an induction of PRI0 and chalcone synthase genes in host and nonhost interactions but delayed responses were observed in the F83005.5 line. The clste12 penetration-deficient $C$. lindemuthianum mutant induced an HR and defense gene expression, showing that perception of nonadapted strains occurs before penetration of epidermal cells. Cytological and transcriptomic analyses performed upon inoculation of near-isogenic $M$. truncatula lines, differing only at the $C$. trifolii resistance locus, $\mathrm{Ct} 1$, with the nonadapted Colletotrichum strain, showed that nonhost responses are similar in the two lines. These included a localized oxidative burst, accumulation of fluorescent compounds, and transient expression of a small number of genes. Host interactions were characterized by a group of defense and signaling-related genes induced at 3 days postinoculation, associated with an accumulation of salicylic acid. Together, these results show that $M$. truncatula displays a rapid and transient response to nonadapted Colletotrichum strains and that this response is not linked to the $C$. trifolii resistance locus.
\end{abstract}

Nonhost resistance (NHR) is defined as the ability of a plant species to resist infection by an entire pathogen species. This form of resistance is less well understood than the one encountered in gene-for-gene systems, in which a specific plant gene confers resistance to a specific pathogen race carrying the cognate avirulence gene. NHR has been linked to multiple constitutive and inducible mechanisms that prevent entry or colonization of the plant (Thordal-Christensen 2003). In particular, NHR may result from the inability of a given pathogen species to overcome, or suppress, basal plant defense reactions triggered by the perception of pattern- or damage-associated molecular

Current address for J. Wong Sak Hoi: Unité des Aspergillus, Institut Pasteur, 25 rue du Dr Roux, 75015 Paris, France.

Corresponding author: B. Dumas; Telephone: (+33) 05621935 03; Email: dumas@scsv.ups-tlse.fr

* The $\boldsymbol{e}$-Xtra logo stands for "electronic extra" and indicates that two supplementary figures and one supplementary table are published online. patterns (PAMPs or DAMPs) found in microbes or initiated by their damaging effects (Zipfel 2008; Hein et al. 2009). Pathogens unable to suppress this initial line of defense are then designated as nonadapted, whereas closely related pathogen species that acquired the ability to overcome PAMP-triggered immunity are designated as adapted.

This situation is particularly illustrated in the case of biotrophic and hemibiotrophic fungal pathogens that exhibit a very narrow host range, such as Blumeria graminis, the powdery mildew pathogen of cereals, whose formae speciales are pathogenic only on individual plant species; for example, $B$. graminis f. sp. graminis on wheat and B. graminis f. sp. hordei on barley (Lipka et al. 2008). Other powdery mildew species that infect Arabidopsis thaliana allowed a direct comparison between defense reactions induced by adapted and nonadapted powdery mildew pathogens on this plant. It was shown that grass and legume powdery mildew pathogens induce a rapid and localized accumulation of cell wall material at the infection site and, in some cases, a hypersensitive response (HR) that restricts the development of the pathogen (Lipka et al. 2008). Mutants impaired in NHR identified PEN-1, a membrane protein implicated in the transport of vesicle required for the delivery of vesicle cargo at the cell periphery, with an essential role in NHR to powdery mildews for rapid deposition of cell-wall materials at the site of pathogen entry (Assaad et al. 2004). However, formation of papillary callose is not required for prepenetration resistance toward three nonadapted Colletotrichum spp.: Colletotrichum truncatum, C. lagenarium, and C. gleosporioides (Shimada et al. 2006), suggesting that NHR of Arabidopsis to these hemibiotrophic pathogens requires additional mechanisms. Indeed, preinvasion resistance was shown to require actin cytoskeleton function. The above examples show that NHR mechanisms displayed by a plant may differ, depending on the nature of the invader; notably, its taxonomic position and pathogenic strategy.

In the course of our studies on legume-Colletotrichum spp. interactions, we have taken advantage of the model plant Medicago truncatula to characterize the responses of this plant to adapted and nonadapted Colletotrichum spp. The three species used in this work (C. trifolii, $C$. lindemuthianum, and $C$. higginsianum) interact with $M$. truncatula, Phaseolus vulgaris, and A. thaliana, respectively, in a race- or cultivar-specific manner (O'Connell et al. 2004; Geffroy et al. 2008; Yang et al. 2008). Like many Colletotrichum spp., these aerial pathogens develop a two-stage hemibiotrophic mode of parasitism on a susceptible host. Infection is initiated by the differentiation of an appressorium, a melanized cell that generates a high internal turgor pressure, allowing mechanical breaching of the plant 
cuticle. The pathogen then penetrates epidermal cells in which it develops intracellularly as a biotroph for 2 to 3 days. It then switches to a necrotrophic, destructive mode of invasion coincident with the differentiation of secondary hyphae. In resistant cultivars, pathogen arrest occurs very soon after initial penetration of host cells as a result of the rapid HR developed at infection sites. Resistance to $C$. trifolii is governed in $M$. truncatula by a single dominant locus, named $C t 1$, located at the upper part of chromosome 4 (Ameline-Torregrosa et al. 2008) from which $R C T 1$, a gene belonging to the toll interleukin 1 receptor nucleotide-binding site leucine-rich repeat family, recently has been shown to confer resistance to $C$. trifolii when transferred to M. sativa (Yang et al. 2008). The resistance of $M$. truncatula to $C$. trifolii is associated with the production of reactive oxygen species, the localized accumulation of fluorescent compounds, and induction of defense gene expression (Torregrosa et al. 2004).

The availability of genetically defined $M$. truncatula lines with contrasting phenotypes (i.e., resistant or susceptible to $C$. trifolii) and of closely related, nonadapted Colletotrichum spp. prompted us to use this pathosystem to compare host and NHR. Cytological and large-scale transcriptomic studies were done, together with the use of a mutant strain impaired in the penetration step, in order to assess the effect of host background on NHR and the requirement of epidermal penetration for NHR to occur.

\section{RESULTS}

\section{Symptoms and defense responses}

\section{of M. truncatula to nonadapted Colletotrichum spp.}

Two $M$. truncatula lines showing a differential phenotype in response to the alfalfa anthracnose pathogen $C$. trifolii were inoculated with $C$. lindemuthianum, a bean pathogen, and $C$. higginsianum, a pathogen of the family Brassicaceae (O'Connell et al. 2004). The C. trifolii-resistant A17 line displayed localized lesions which began to appear 2 to 3 days postinoculation (dpi) on detached leaves and were still visible 7 dpi, typical of the HR previously described (Torregrosa et al. 2004) (Fig. 1A). In contrast, the susceptible-F83005.5 line showed severe anthracnose lesions at the inoculation sites, as observed at 7 dpi (Fig. 1D). Inoculation of the two lines with C. lindemuthianum or C. higginsianum induced HR-like lesions (Fig. 1B, C, E, and F), confirming that these two fungal species are nonadapted on $M$. truncatula.

A kinetic study of the expression of two defense genes, a chalcone synthase (CHS1; GenBank accession no. AJ277211) (Bonanomi et al. 2001) and a pathogenesis-related class 10 protein (PR10-1; GenBank accession no. Y08641) (Gamas et al. 1998), previously shown to be induced in response to C. trifolii inoculation (Torregrosa et al. 2004), was performed after inoculation of detached leaves with adapted or nonadapted Colletotrichum spp. Plant tissues were sampled at times corresponding to different stages of pathogenesis: i) conidia germination and appressoria differentiation, (compatible and incompatible interactions) at $16 \mathrm{~h}$ postinoculation (hpi); ii) penetration and establishment of the biotrophic phase (compatible interactions) or beginning of the hypersensitive cell death (incompatible interactions) at $40 \mathrm{hpi}$; and iii) switch to the necrotrophic phase (compatible interaction) or completion of the HR (incompatible interaction) at $72 \mathrm{hpi}$. Transcript accumulation of the two marker genes was observed at $16 \mathrm{hpi}$ in the resistant line inoculated by either the adapted or the nonadapted Colletotrichum strains but transcripts were not detected in the susceptible line at this time point (Fig. 2). At $40 \mathrm{hpi}$, transcript accumulation of marker genes was observed in the two lines in compatible and incompatible interactions. At $72 \mathrm{hpi}$, transcript accumulation of PRIO-1 and CHS1 was essentially found in the compatible interaction (F83005.5-C. trifolii).

Together, these analyses showed that nonadapted Colletotrichum spp. triggered similar HR-like lesions in the two lines A17 and F83005.5. However, gene expression studies revealed a faster defense response in A17 than in F83005.5 to the nonadapted and adapted Colletotrichum strain on A17.

\section{Perception of a nonadapted C. lindemuthianum mutant strain impaired in the appressoria-mediated penetration step.}

The finding that defense gene expression was induced on A17 plants at the onset of fungal penetration prompted us to examine whether inductive signals were released at an earlier stage of pathogenesis. For these experiments, we used a previously characterized nonpathogenic mutant of $C$. lindemuthianum disrupted in the CLSTE12 transcription factor (Wong Sak Hoi et al. 2007). The clste12 mutant formed melanized appressoria with basal penetration pores but was impaired in the subsequent steps required for pathogen entry and invasive growth in its host, a defect that has also been shown in other pathogens (Park et al. 2002; Deng et al. 2007; Yang and Chung 2010). In addition, the mutant is defective in the production of cell surface adhesion components and hydrolytic enzymes (Wong Sak Hoi et al. 2007). The clste12 mutant formed appressoria on $M$. truncatula leaves within $16 \mathrm{hpi}$ (data not shown), and induced the accumulation of fluorescent compounds at $3 \mathrm{dpi}$ and the formation of $\mathrm{HR}$-like lesions at $7 \mathrm{dpi}$ (Fig. 3), similar to the wild-type $C$. lindemuthianum strain. This indicates that perception of $C$. lindemuthianum is independent of epidermal cell penetration and invasive growth.

At $16 \mathrm{hpi}$, the clste 12 mutant induced an expression pattern of PR10-1 and CHS similar to the wild-type strain (Fig. 4). However, expression of PRIO-1 and CHSI in clste12-inoculated A17 leaves at 40 hpi was significantly lower than in the

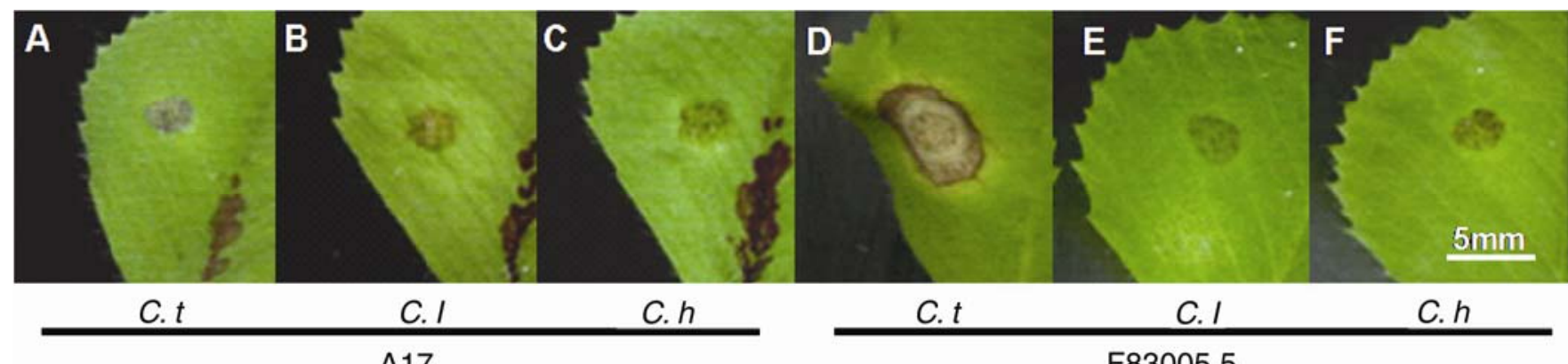

$\mathrm{A} 17$

F83005.5

Fig. 1. Macroscopic symptoms of Medicago truncatula leaves inoculated with Colletotrichum spp. Macroscopic symptoms at 7 days postinoculation. A, A17 inoculated with Colletotrichum trifolii (C.t). B, A17 inoculated with C. lindemuthianum (C.l). C, A17 inoculated with C. higginsianum (C.h). D, F83005.5 inoculated with $C$. trifolii. E, F83005.5 inoculated with $C$. lindemuthianum. F, F83005.5 inoculated with $C$. higginsianum. 
case of the wild-type strain, indicating that development of a penetration peg, or production of CLSTE12-regulated effectors, is required for the duration of the defense response.

Transcriptomic signatures associated with host and NHR.

A major quantitative trait locus, named $C t 1$, involved in resistance to $C$. trifolii races 1 and 2, was previously detected near the top of chromosome 4, using the LR5 (A17-Jemalong $\times$ F83005.5) F7 recombinant inbred line (RIL) population (Ameline-Torregrosa et al. 2008). This region also contains the $R C T 1$ gene, which confers resistance to C. trifolii when transferred to susceptible alfalfa plants (Yang et al. 2008). Two nearisogenic lines (NIL), named 210A and 210F, were selected after selfing of an F7 line (line 210) showing residual heterozygosity inside the $C t l$ region. $210 \mathrm{~A}$ is resistant to $C$. trifolii whereas 210F is susceptible (Supplementary Fig. S1) (M. Cazaux and C. Jacquet, unpublished work). To determine the role in the nonhost response of this $C$. trifolii resistance locus, these two isogenic lines were inoculated with $C$. trifolii or C. lindemuthianum co-
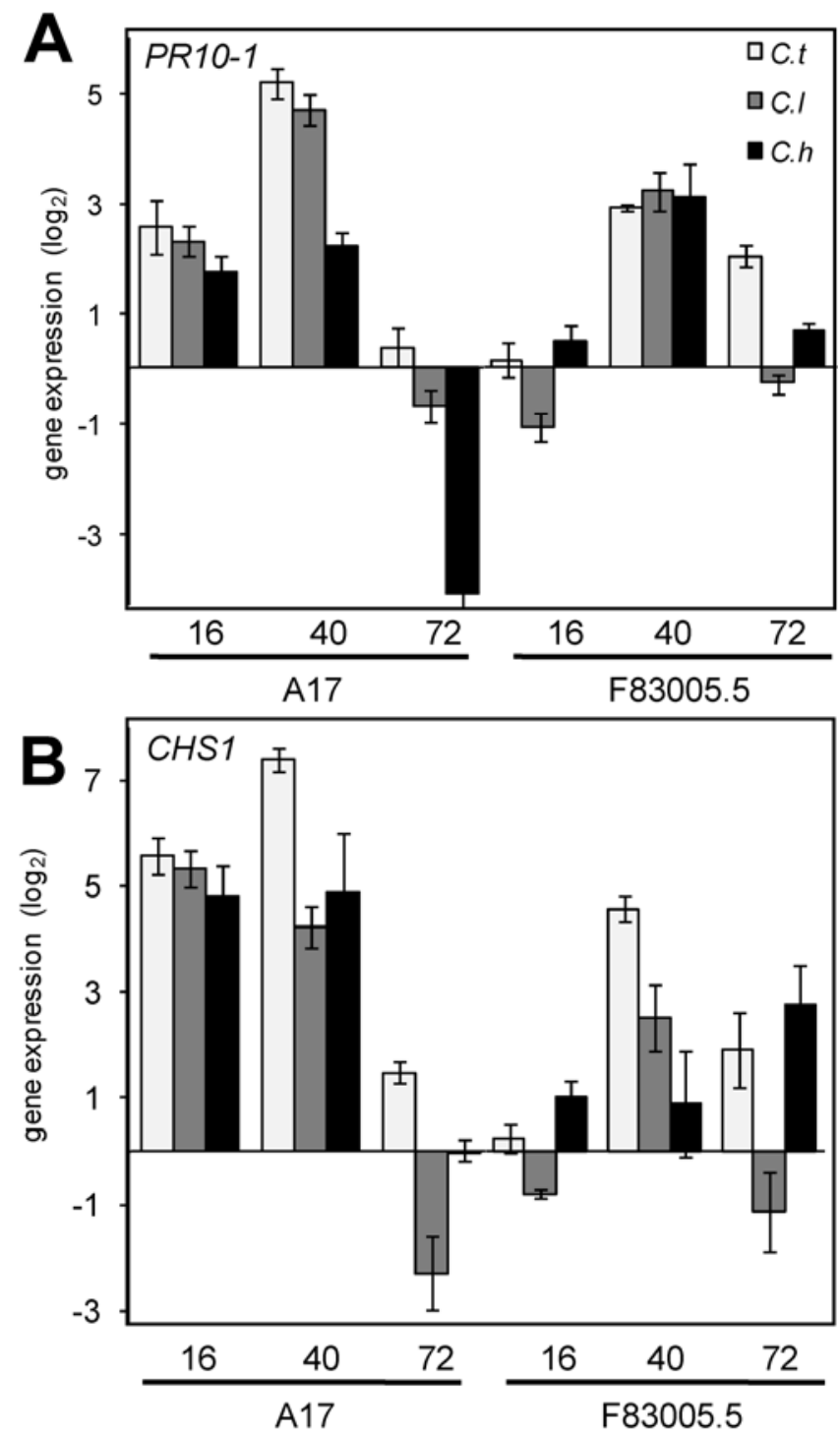

Fig. 2. Gene expression after inoculation by Colletotrichum spp. A17 and F83005.5 were inoculated with Colletotrichum trifolii (C.t), C. lindemuthianum $(C . l)$, or $C$. higginsianum (C.h). Relative transcript levels ratios were calculated between gene expression measured in inoculated and noninoculated leaves and was expressed in $\log _{2}$. Gene expression was measured at 16 , 40, and $72 \mathrm{~h}$ after inoculation. A, Expression of the PR10-1 gene (Y08641). B, Expression of the chalcone synthase 1 gene (CHS1; AJ277211.1). nidia. Macroscopic symptoms identical to those obtained with the parental lines were obtained (Fig. 5A). In the case of host and nonhost incompatible interactions, a localized accumulation of hydrogen peroxide was detected at 2 dpi upon staining the tissues with diaminobenzidine (DAB) (Fig. 5B). Hypersensitive lesions were surrounded by cells that accumulated fluorescent compounds (Fig. 5C). No clear differences were noticed at the cellular levels between host and nonhost defense reactions except that, in the case of the host incompatible interactions, DAB staining heavily labeled conidia and appressoria as well as the germ tube, reflecting a strong stress response in fungal cells. The expression of the two defense marker genes, PR10-1 and CHS1 (Fig. 5D), was studied in the two lines inoculated by spraying conidial suspensions on whole plants. As previously observed in the case of the parental lines, no specific expression pattern distinguishing host and nonhost response emerged from these analyses, except that the stronger gene induction was observed in the incompatible interaction with the adapted strain (i.e., the $210 \mathrm{~A}$ line in response to $C$. trifolii at $1 \mathrm{dpi}$ ).

Large-scale transcriptomic analyses were performed in order to compare NHR and host resistance in these genetically defined lines differing at the $C t 1$ locus. Inoculations were done on 2-week-old intact plants by spraying a conidial suspension of $C$. trifolii or $C$. lindemuthinaum. Due to their taxonomic proximity, $C$. trifolii and $C$. lindemuthianum were used in this experiment. RNA was extracted from leaves collected at 1 and 3 dpi from three independent experiments and transcript profiling was performed using Mt16kOLI1Plus chips (Thompson et al. 2005), allowing us to monitor the expression of approximately 16,000 genes. Data from inoculated and corresponding control (noninoculated) plants were used to assess the expression ratio of each gene. After analysis of variance (ANOVA), a gene was considered responsive to the pathogen if it was associated with a $P$ value $\leq 0.05$ and regarded as differentially expressed if the absolute value of the $\log _{2}$ ratio was $\geq 0.584(>1.5$ fold induction or $<0.67$ fold repression). Examining each experimental data set individually, a low number of genes were differentially expressed at $1 \mathrm{dpi}$ in $210 \mathrm{~A}$ and $210 \mathrm{~F}$ inoculated with nonadapted $C$. lindemuthianum and adapted $C$. trifolii, respectively. This result is probably due to the inoculation procedure which produced dispersed and localized micro-HR

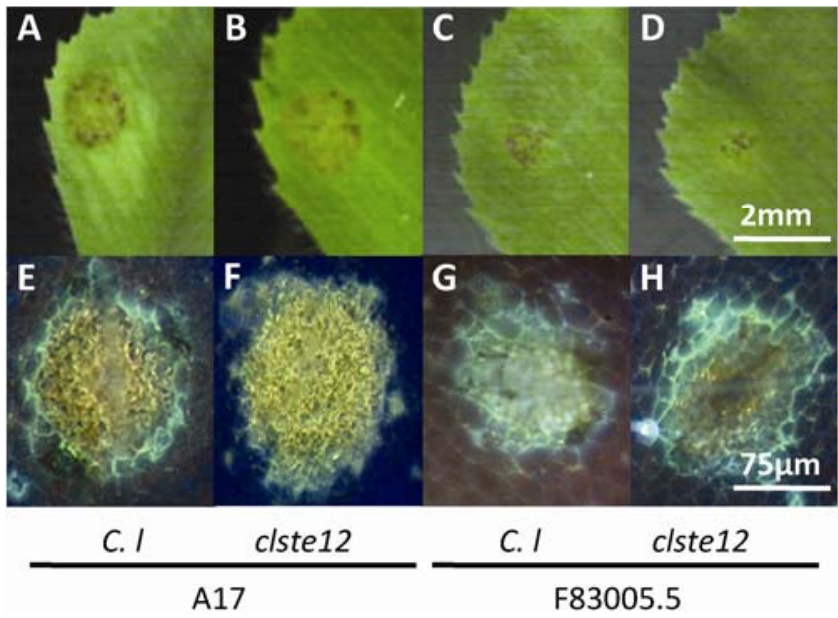

Fig. 3. Macroscopic symptoms and epifluorescence microscopy of Medicago truncatula leaves inoculated with Colletotrichum lindemuthianum. Macroscopic symptoms at 7 days postinoculation (dpi) (upper panel) and epifluorescence microscopy at 2 dpi (lower panel). A and E, A17 inoculated with the wild-type strain of $C$. lindemuthianum $(C . l)$. B and $\mathbf{F}, \mathrm{A} 17$ inoculated with the clste 12 mutant of $C$. lindemuthianum. $\mathbf{C}$ and $\mathbf{G}, \mathrm{F} 830005.5$ inoculated with the wild-type strain of $C$. lindemuthianum. $\mathbf{D}$ and $\mathbf{H}$, F830005.5 inoculated with the clste 12 mutant of $C$. lindemuthianum. 
lesions, leading to a strong dilution of induced cells to unaffected tissues. More than half of these genes were differentially regulated by adapted and nonadapted Colletotrichum strains, suggesting that host and nonhost incompatible reactions largely overlap (Fig. 6A).

At $3 \mathrm{dpi}$, differential expression of many more genes was observed from $210 \mathrm{~A}$ and $210 \mathrm{~F}$ inoculated with $C$. trifolii than with $C$. lindemuthianum (Table 1). This was obviously related to the continuing development of the pathogen during the compatible host interaction but also during the incompatible interaction, suggesting that, in this case, the pathogen was arrested at a later stage of development than during nonhost interactions.

Hierarchical clustering was performed for all genes differentially expressed in at least one interaction. Four major groups
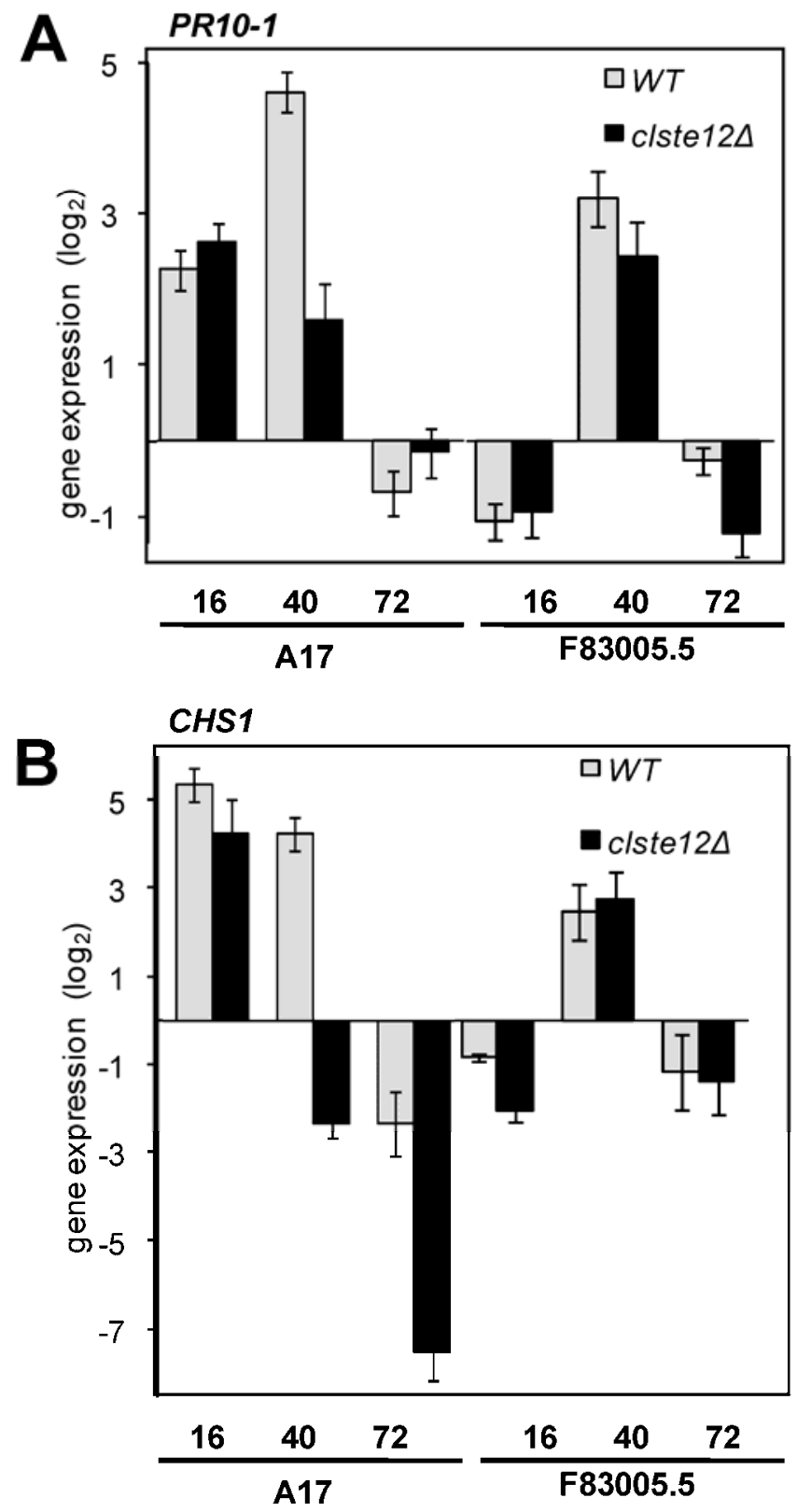

Fig. 4. Defense gene expression in Medicago truncatula leaves after inoculation by a penetration mutant of Colletotrichum lindemuthianum. The A17 and F83005.5 lines of M. truncatula were inoculated with the wildtype or clste12 mutant strains of C. lindemuthianum. Relative transcript level corresponding to A, the PR10-1 (Y08641) gene and B, the chalcone synthase 1 gene (CHS1; AJ277211.1) gene was measured at 16, 40, and 72 $\mathrm{h}$ after inoculation. Data are expressed as the $\log _{2}$ ratio between gene expression measured in inoculated and noninoculated leaves.
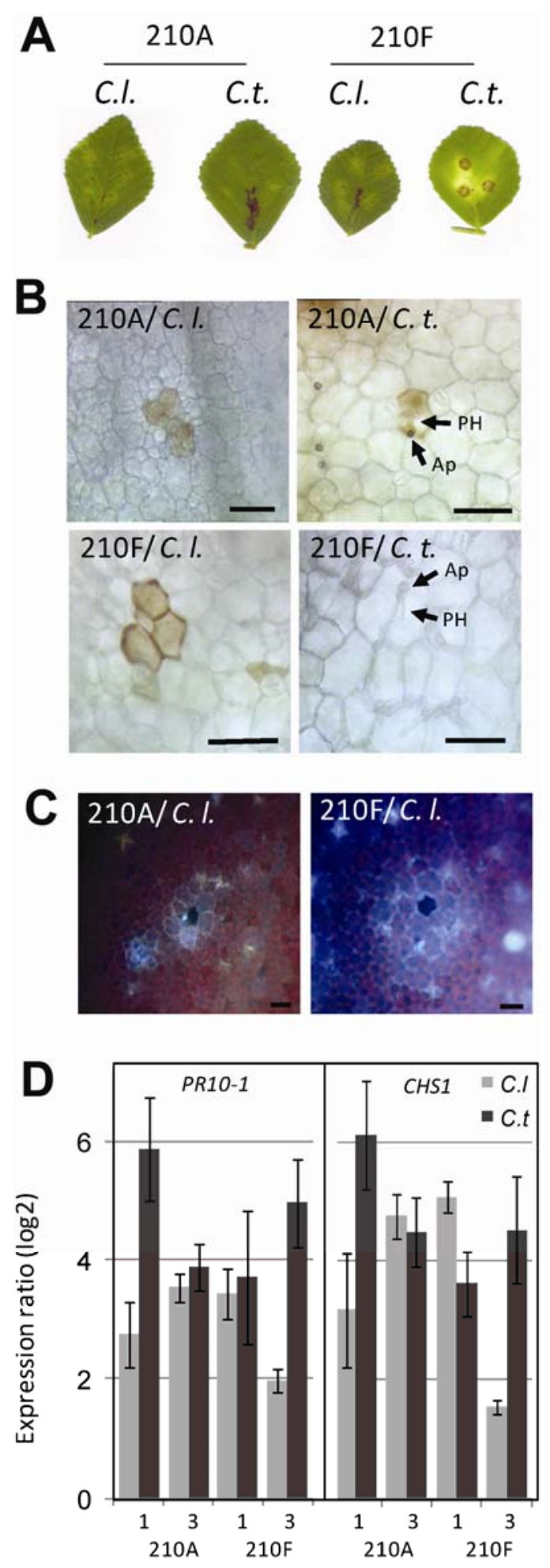

Fig. 5. Nonhost and host defense reactions induced by Colletotrichum spp. in near-isogenic Medicago lines. The 210A (Colletotrichum trifolii resistant) and 210F lines (C. trifolii susceptible) were inoculated with conidial suspensions of the $C$. lindemuthianum $(C$. l.) or the $C$. trifolii $(C . t$.) strains. A, Macroscopic symptoms were observed at 6 days postinoculation (dpi). A and E, 210A inoculated with C. trifolii (C.t). B, Diaminobenzidine (DAB) staining of inoculated leaves at 2 dpi revealing single-cell oxidative burst. Note the detection of DAB-positive cells only in the case of nonhost and host-incompatible interactions. Bar $=40 \mu \mathrm{m}$. Ap, Appressorium; PH, primary hyphae. C, Epifluorescence microscopy at 3 dpi revealing a fluorescent ring of cells around the hypersensitive response cell. Bar $=40 \mu \mathrm{m}$. D, PR10-1 and $C H S$ expression at 1 and 3 dpi in 210A or $210 \mathrm{~F}$ leaves inoculated with conidial suspension of $C$. lindemuthianum (gray bars) or C. trifolii (black bars). 
could be distinguished (Fig. 6B). Group I represented genes induced at $1 \mathrm{dpi}$, mainly during NHR of the two lines to C. lindemuthianum spp. and during host resistance of $210 \mathrm{~A}$ to $C$. trifolii (Table 2). Group I was enriched in genes with a signaling and defense function (Fig. 6B). Among them, genes associated with cell wall structure and modification, such as glycine- or hydroxyproline-rich (glyco) proteins and peroxidase, were only induced in incompatible interactions. In contrast, induction was very low in the susceptible line $210 \mathrm{~F}$ inoculated with C. trifolii (compatible interaction), suggesting the ability of the pathogen to partially suppress early defense induction by this line. Some defense genes from group I, including isoflavone

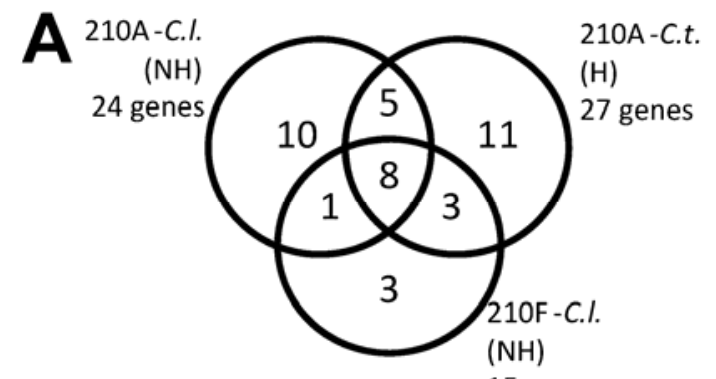

15 genes
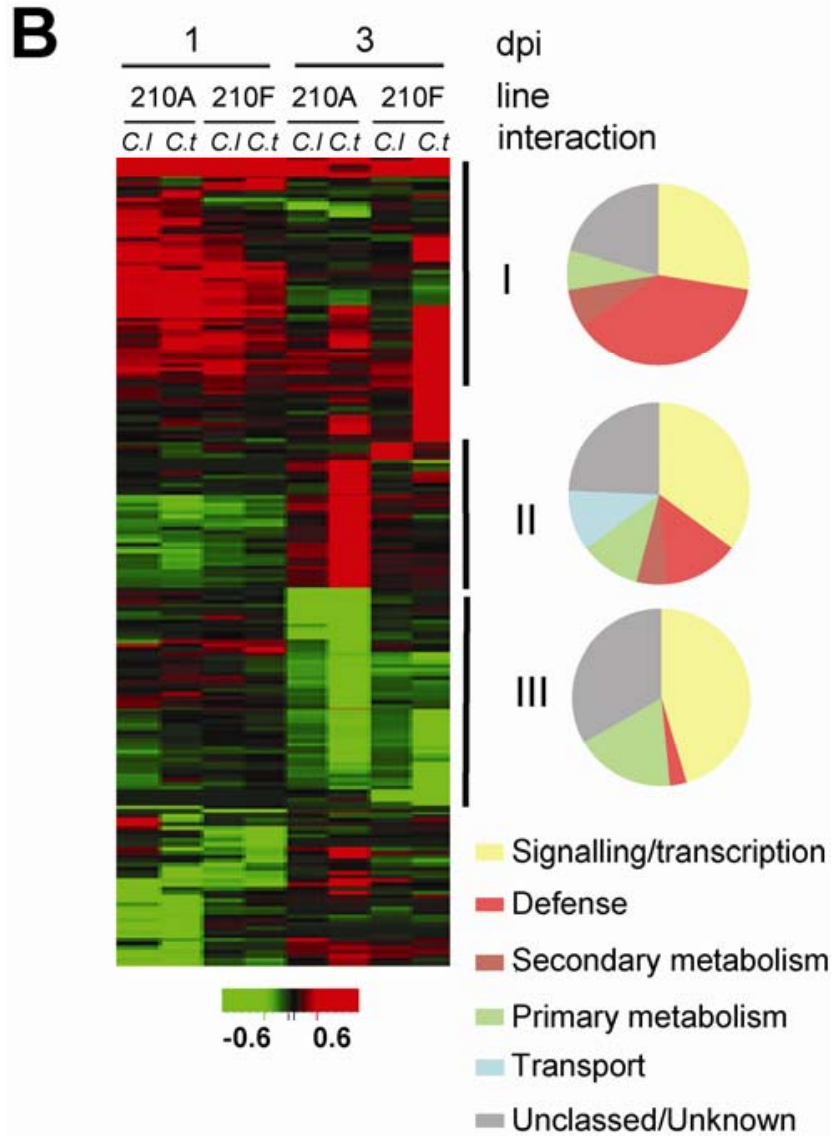

Fig. 6. Clustering of microarray data and functional classification of coregulated genes. A, Venn diagram to compare the set of induced genes at 1 day postinoculation (dpi) during host and nonhost incompatible interactions. B, Hierarchical clustering of microarray data issued from each of the Colletotrichum spp.-Medicago truncatula interactions using the HCE3.5 software with the complete linkage method and the Manhattan distance measure. Three classes of genes were defined according to their expression profiles. Class I corresponds to genes upregulated at $1 \mathrm{dpi}$, class II to genes upregulated at $3 \mathrm{dpi}$, and class 3 to genes downregulated at $3 \mathrm{dpi}$. Genes corresponding to the three classes were further grouped according to their predicted function. reductase and chalcone synthase, were induced during the compatible situation but at a later stage of infection. Group II included genes specifically induced in the host-incompatible interaction at 3 dpi (Table 3), while group III comprised repressed genes at $3 \mathrm{dpi}$, mainly in the host-incompatible and, to a lesser extent, the compatible interactions (Table 4). Most group II genes fell into the signaling functional class, whereas group III genes belonged to signaling and primary metabolism classes. Interestingly, among repressed genes, two of them were similar to the Arabidopsis negative regulators of defense responses, NPR3 and SAC9 (Williams et al. 2005; Zhang et al. 2006), and were only repressed by $210 \mathrm{~A}$ in response to nonadapted and adapted Colletotrichum spp.

To validate microarray data, expression of five differentially expressed genes was analyzed by quantitative reverse-transcription polymerase chain reaction (qRT-PCR) (Supplementary Fig. S2). The results were similar to the microarray data except for some experimental points for which contrasting results were obtained. Importantly, similar expression patterns were observed for genes showing a differential expression in a specific interaction such as the adenylate-kinase gene and the HRGP gene which were induced at $1 \mathrm{dpi}$ in the resistant line upon inoculation of the nonadapted strain.

NHR may involve different hormone signaling pathways depending on the nature of the pathogen (Nurnberger and Lipka, 2005). The transcriptomic analyses of nonhost and host interactions did not reveal clear effects of inoculation by Colletotrichum spp. on plant hormone signaling. However, it was previously shown that the salicylic acid (SA) pathway is involved in anthracnose basal resistance, as suggested by the increased susceptibility to $C$. higginsianum of an Arabidopsis line expressing the NahG gene (O'Connell et al. 2004). Thus, accumulation of SA was investigated in $210 \mathrm{~A}$ and $210 \mathrm{~F}$ leaves inoculated with $C$. trifolii or $C$. lindemuthianum. A significant increase of SA concentration was detected only in C. trifoliiinoculated plants at 3 dpi (Fig. 7). However, SA accumulation was higher in the susceptible line compared with the resistant one, suggesting that SA accumulation is induced by the development of anthracnose symptoms, which results in a greater number of cells inducing defense reactions.

\section{DISCUSSION}

Although NHR has been recognized for many years, the molecular mechanisms that underlie its various steps are still largely unknown. The knowledge gained on PAMP-triggered basal defense immunity and on gene-for-gene resistance, together with the use of model plant and pathogen systems, will increase understanding of this important aspect of durable resistance (Boller and Felix 2009). This was recently illustrated by comparative analyses of the NHR of $A$. thaliana to nonadapted biotrophic pathogens (powdery mildews) and hemibiotrophic pathogens (Colletotrichum spp.) (Zimmerli et al. 2004; Shimada et al. 2006; Lipka et al. 2008). It was notable that NHR can share common cellular and molecular traits with host basal defense. However, the effect of the genetic background

Table 1. Number of up- and downregulated genes in Medicago truncatula near-isogenic lines (NIL) at 1 and 3 days postinoculation (dpi) with Colletotrichum lindemuthianum and C. trifolii

\begin{tabular}{llccccc}
\hline & & \multicolumn{2}{c}{ Upregulated } & & \multicolumn{2}{c}{ Downregulated } \\
\cline { 3 - 4 } \cline { 7 - 7 } NIL & \multicolumn{1}{c}{ Species } & 1 dpi & 3 dpi & & 1 dpi & 3 dpi \\
\hline \multirow{2}{*}{$210 \mathrm{~A}$} & C. lindemuthianum & 22 & 4 & & 15 & 12 \\
& C. trifoli & 25 & 47 & & 22 & 33 \\
\multirow{2}{*}{$210 \mathrm{~F}$} & C. lindemuthianum & 15 & 10 & & 3 & 2 \\
& C. trifoli & 11 & 49 & & 7 & 23 \\
\hline
\end{tabular}


of the plant was not controlled in these studies. Our purpose was to use the interaction of the model plant $M$. truncatula with $C$. trifolii to directly compare the effect of the plant genetic background on host resistance and NHR to Colletotrichum spp. that display an identical mode of parasitism.

In this study, we showed that many aspects of the resistance of M. truncatula to nonadapted Colletotrichum strains are quite similar to the incompatible reaction induced by the adapted strain on the resistant line. Most notably, all incompatible interactions were characterized by the rapid formation of a localized HR-like lesion at inoculation sites, at times when the compatible interaction was symptomless. Recently, Mysore and Ryu (2004) distinguished two types of NHR. Type I relates to pathogens that are not able to overcome a first layer of preformed and generalelicitor induced defense, whereas type II corresponds to pathogens that induce an HR and are recognized through the perception of more specific motifs. The present study shows that the response of $M$. truncatula to nonadapted Colletotrichum spp. falls into type II NHR. This is in contrast with nonhost interactions involving $A$. thaliana and the two nonadapted $C$. lagenarium and $C$. gleosporioides pathogens, in which papillary callose formation was observed but not HR cell death (Shimada et al. 2006). Absence of an HR also characterized the NHR of Arabidopsis to the bean pathogen Pseudomonas syringae pv. phaseolicola (Tao et al. 2003). This does not reflect a general failure of Arabidopsis to mount an HR upon NHR because cell death had been detected in this plant in response to nonadapted powdery mildew strains (Zimmerli et al. 2004).

The present work also highlighted additional features of the HR response. Thus, it appeared that the HR symptoms of NHR can occur in the absence of epidermal cell penetration, as ob- served in response to the clste 12 mutant of $C$. lindemuthianum. Although impaired in cell surface properties and invasive growth, as previously reported (Wong Sak Hoi et al. 2007), we found that this mutant had retained the ability to induce HR and associated defense gene expression in M. truncatula. This is reminiscent of another $C$. lindemuthianum mutant affected in appressorial-mediated penetration which was still able to induce plant responses such as superoxide production and induction of PR proteins when inoculated onto bean leaves (Veneault-Fourrey et al. 2005). These results indicate that fungal signals are produced before establishment of the biotrophic phase during both host and nonhost interactions.

These signals can be either general elicitors, such as polysaccharide fragments or cell-wall-degrading enzymes, or more specific microbial effectors. $C$. lindemuthianum is a potential source of general elicitors, notably derived from chitin; it also secretes an endopolygalacturonase that releases oligogalacturonide elicitors from plant cell walls (Herbert et al. 2002; Boudart et al. 2003). However, the resistance of $M$. truncatula to $C$. trifolii is mediated by the $C t 1$ locus, which comprised several resistancelike genes, notably RCT1 (Ameline-Torregrosa et al. 2008; Yang et al. 2008) and a close ortholog of $R C T 1$, present in the susceptible line. This gene is constitutively expressed and alternatively spliced, giving rise to two transcripts in the resistant line; however, only the longest one in the susceptible line (Yang et al. 2008). One may hypothesize that the type II NHR to $C$. lindemuthianum involves functional homologues of the resistanceavirulence gene pairs that govern host resistance in this system. In such a context, the remnant expression of RCT1 might significantly contribute to the NHR of $210 \mathrm{~F}$ but is clearly insufficient to confer resistance of $C$. trifolii.

Table 2. Genes belonging to group I, mainly upregulated in at least one interaction between Medicago truncatula and Colletotrichum spp. at 1 dpi ${ }^{\mathrm{a}}$

\begin{tabular}{|c|c|c|c|c|c|c|}
\hline \multirow[b]{2}{*}{ Mt16kOLIplus } & \multirow[b]{2}{*}{ Annotation } & \multirow[b]{2}{*}{ TIGR v5 } & \multicolumn{2}{|c|}{ 210A } & \multicolumn{2}{|c|}{$210 \mathrm{~F}$} \\
\hline & & & Nonhost & Host & Nonhost & Host \\
\hline \multicolumn{7}{|c|}{ Signaling/transcription } \\
\hline MT003492 & Adenylate kinase & TC47188 & 0.64 & -0.10 & -0.02 & -0.10 \\
\hline MT009512 & Steroid-binding protein & TC54196 & 0.65 & -0.44 & -0.03 & -0.21 \\
\hline MT016327 & Transcription factor B3-type & BG646843 & 0.93 & 1.03 & 1.07 & 0.67 \\
\hline MT009107 & Transcription factor $\mathrm{CCCH}$-type & TC53754 & 0.85 & 0.58 & 1.01 & 0.66 \\
\hline MT012881 & Frigida like & TC57871 & 0.62 & 0.58 & 0.68 & 0.58 \\
\hline MT016420 & NAC transcription factor & CA917398 & 0.64 & 0.61 & 0.50 & 0.37 \\
\hline MT004642 & RING-finger protein & TC48442 & 1.29 & 1.17 & 1.62 & 1.21 \\
\hline МT007046 & SNF2 related $\mathrm{H}$ box helicase & TC51155 & 0.69 & 0.61 & 0.41 & -0.01 \\
\hline MT002007 & Polyadenylate-binding protein & TC45554 & 0.46 & 0.27 & 0.59 & 0.29 \\
\hline \multicolumn{7}{|l|}{ Defense } \\
\hline MT014134 & Hydroxyproline-rich protein & TC43063 & 0.59 & 0.45 & 0.39 & 0.00 \\
\hline MT014142 & Hydroxyproline-rich protein & TC43019 & 0.73 & 0.56 & 0.43 & 0.02 \\
\hline МТ014143 & Hydroxyproline-rich protein & TC43082 & 0.68 & 0.52 & 0.38 & 0.02 \\
\hline МT009425 & Glycine-rich protein & TC54102 & 0.56 & 0.64 & 0.73 & 0.51 \\
\hline МТ014250 & Glycine-rich protein & TC43292 & 0.68 & 0.66 & 0.61 & 0.41 \\
\hline MT015604 & Peroxidase & TC53280 & 0.63 & 0.50 & 0.24 & 0.21 \\
\hline MT014168 & PR10 & TC43135 & 0.18 & 0.47 & 0.60 & 0.39 \\
\hline МТ015101 & PR10 & TC51050 & 0.22 & 0.59 & 0.63 & 0.29 \\
\hline MT015362 & PR10 & TC51765 & 0.64 & 0.91 & 0.57 & 0.39 \\
\hline MT014167 & PR10 & TC43134 & 1.05 & 1.51 & 1.05 & 1.06 \\
\hline MT007530 & Iron-stress-related protein & TC51883 & 0.62 & 0.30 & 0.23 & 0.08 \\
\hline \multicolumn{7}{|c|}{ Secondary metabolism } \\
\hline MT014241 & Isoflavone reductase & TC43281 & 0.81 & 1.00 & 0.61 & 0.47 \\
\hline МТ014270 & Chalcone reductase & TC43329 & 0.57 & 1.04 & 0.82 & 0.73 \\
\hline \multicolumn{7}{|c|}{ Primary metabolism } \\
\hline МТ001267 & Carbonic anhydrase & TC44723 & 0.82 & 0.13 & 0.10 & 0.15 \\
\hline МT013904 & Phosphoglucomutase & TC58970 & 0.59 & 0.64 & 0.48 & 0.33 \\
\hline \multicolumn{7}{|c|}{ Unclassed/unknown } \\
\hline MT013021 & Unknown & TC58019 & 1.09 & 0.60 & 0.91 & 0.59 \\
\hline MT004228 & Unknown & TC47998 & 0.67 & 0.32 & -0.38 & -0.35 \\
\hline MT011615 & Unknown & TC56486 & 0.62 & 0.26 & 0.71 & 0.39 \\
\hline МT015286 & Unknown & TC51492 & 0.43 & 0.48 & 0.61 & 0.52 \\
\hline МТ005919 & Unknown & TC49804 & 0.61 & 0.57 & 0.53 & 0.21 \\
\hline
\end{tabular}

a Expression ratio is expressed in $\log _{2}$. Values greater than $0.58\left(\log _{2} 1.5\right)$ are in bold. dpi = days postinoculation. 
For a more precise insight into the effect of the genetic background on NHR, we then concentrated on two $M$. truncatula NIL and performed cytological analyses and large-scale transcriptomic analyses after inoculation with the two closely related species, $C$. lindemuthianum and $C$. trifolii. Nonhost responses observed in $210 \mathrm{~A}$ and $210 \mathrm{~F}$ were highly similar, with the development of necrotic spots and, at an earlier stage, the detection of DAB-positive cells suggesting that nonhost responses are independent of the $C$. trifolii resistance locus. As mentioned above, these cytological reactions are typical of the type II NHR detected in various plant-pathogen combinations such as interactions between rice genotypes and nonadapted Magnaporthe isolates (Faivre-Rampant et al. 2008).

Results from the transcriptomic analyses revealed that most of the genes induced at $1 \mathrm{dpi}$ by $C$. lindemuthianum in the $210 \mathrm{~F}$ line are also induced in the $210 \mathrm{~A}$ line, confirming that the nonhost response is similar in these two lines, differing only in the $C t l$ region. Those similar patterns were strictly correlated with the appearance of an HR, in contrast to what was reported for Arabidopsis-P. syringae interactions, in which similar molecular responses to host resistance and NHR were observed but without an HR (Tao et al. 2003).

At 3 dpi, a small number of genes were differentially expressed in the nonhost combinations, whereas the host interac- tions were characterized by the sustained expression of additional sets of defense genes and an increase in free SA. This indicates that restriction of fungal development mediated by the $C t 1$ locus occurred later in the host-incompatible interaction than in the nonhost interactions and that host and NHR s involve different recognition mechanisms.

Our study shows that the susceptible line is able to mount a rapid and efficient HR toward nonhost strains but not toward the adapted Colletotrichum spp. This could be due to the inability to recognize a $C$. trifolii-specific cell-death elicitor but could also involve fungal effectors involved in cell-death suppression. Specific cell death or basal immunity suppressors have been identified in bacteria (Abramovitch et al. 2003), oomycetes (Dou et al. 2008; Bos et al. 2009), and fungi (Uppalapati et al. 2004) but still await their identification in Colletotrichum spp. The Colletotrichum genus, which comprises highly specialized species, is particularly suited to investigate the basis of host-pathogen compatibility.

\section{MATERIALS AND METHODS}

Plant materials and growth conditions.

M. truncatula Gaertn. A17 and F83005.5 lines were provided by J. M. Prospéri (INRA SGAP Laboratory, Mauguio, France).

Table 3. Genes belonging to group II, mainly upregulated during interaction between the Medicago truncatula resistant line (210A) and Colletotrichum spp. at $3 \mathrm{dpi}^{\mathrm{a}}$

\begin{tabular}{|c|c|c|c|c|c|c|}
\hline \multirow[b]{2}{*}{ Mt16kOLIplus } & \multirow[b]{2}{*}{ Annotation } & \multirow[b]{2}{*}{ TIGR v5 } & \multicolumn{2}{|c|}{ 210A } & \multicolumn{2}{|c|}{$210 \mathrm{~F}$} \\
\hline & & & Nonhost & Host & Nonhost & Host \\
\hline \multicolumn{7}{|c|}{ Signaling/transcription } \\
\hline МТ016329 & AP2/EREBP transcription factor & AW689511 & -0.01 & 0.72 & -0.12 & -0.18 \\
\hline МТ009781 & Adenylate-cytidine kinase & TC54494 & 0.22 & 0.60 & 0.02 & 0.16 \\
\hline МТ014479 & Early flowering transcription factor & TC44345 & -0.08 & 0.72 & -0.04 & 0.07 \\
\hline МТ012308 & Serine Threonine kinase & TC57250 & 0.26 & 0.66 & 0.38 & 0.30 \\
\hline МТ002241 & Serine Threonine kinase & TC45821 & 0.20 & 0.59 & 0.18 & 0.20 \\
\hline МТ001984 & Calmodulin-binding protein & TC45530 & 0.35 & 0.71 & -0.01 & 0.05 \\
\hline МТ007720 & CDP-DG:inositol transferase & TC52127 & 0.38 & 0.61 & 0.01 & -0.21 \\
\hline МТ010770 & Phospholipase & TC55571 & -0.05 & 1.06 & -0.05 & 0.02 \\
\hline МТ015913 & Lipoxygenase & TC56844 & 0.13 & 0.60 & -0.11 & 0.46 \\
\hline МT002447 & Auxin response factor & TC46043 & 0.39 & 0.60 & 0.19 & 0.32 \\
\hline \multicolumn{7}{|l|}{ Defense } \\
\hline МT002340 & NADP-thioredoxin reductase A & TC45928 & 0.24 & 0.74 & 0.17 & 0.15 \\
\hline МТ013730 & Amine oxidase & TC58780 & 0.27 & 0.64 & 0.22 & 0.23 \\
\hline МT012243 & Heat shock protein & TC57180 & 0.24 & 0.61 & 0.13 & 0.02 \\
\hline МТ009896 & Dehydrated response protein & TC54626 & 0.30 & 0.60 & 0.15 & 0.17 \\
\hline MT012742 & Extensin & TC57726 & -0.11 & 0.78 & 0.01 & -0.05 \\
\hline \multicolumn{7}{|c|}{ Secondary metabolism } \\
\hline MT008064 & Dirigent-like protein & TC52540 & 0.15 & 0.62 & -0.03 & 0.41 \\
\hline МТ004268 & Squalene monooxygenase & TC48042 & 0.19 & 0.59 & 0.26 & -0.01 \\
\hline \multicolumn{7}{|c|}{ Primary metabolism } \\
\hline МT005526 & Adenylsulfate kinase & TC49389 & 0.24 & 0.69 & 0.14 & 0.24 \\
\hline МT011342 & Glucan phosphorylase & TC56194 & 0.38 & 0.64 & 0.21 & 0.23 \\
\hline МT003867 & Aspartic-type endopeptidase & TC47605 & 0.07 & 1.11 & 0.14 & 0.37 \\
\hline МТ007992 & Fribrillin & TC52459 & 0.39 & 0.65 & 0.01 & -0.10 \\
\hline \multicolumn{7}{|c|}{ Transport/secretion } \\
\hline МТ001650 & Small Rab GTPase & TC45153 & 0.18 & 0.63 & 0.05 & 0.02 \\
\hline МТ003691 & Prefolding protein & TC47408 & 0.23 & 0.62 & 0.20 & 0.17 \\
\hline МТ008913 & Nicastrin-related protein & TC53537 & 0.11 & 0.69 & 0.35 & -0.22 \\
\hline МT009415 & $\mathrm{ABC}$ transporter & TC54092 & 0.16 & 0.74 & 0.09 & 0.02 \\
\hline MT011180 & $\mathrm{Na} / \mathrm{H}$ exchanger & TC56021 & 0.35 & 0.69 & 0.25 & 0.06 \\
\hline MT011179 & Transportin & TC56020 & 0.14 & 0.62 & 0.11 & -0.03 \\
\hline МТ002528 & Boron transporter & TC46129 & 0.26 & 0.61 & 0.14 & 0.22 \\
\hline \multicolumn{7}{|c|}{ Unclassed/unknown } \\
\hline МT011051 & Unknown & TC55880 & 0.43 & 0.75 & 0.15 & 0.12 \\
\hline МT003030 & Unknown & TC46683 & 0.20 & 0.68 & 0.23 & 0.15 \\
\hline МТ003278 & Unknown & TC46952 & 0.36 & 0.67 & 0.10 & 0.09 \\
\hline МТ011318 & Unknown & TC56170 & 0.39 & 0.66 & 0.18 & 0.24 \\
\hline МТ003890 & Unknown & TC47631 & 0.09 & 0.61 & 0.32 & 0.23 \\
\hline МТ004527 & Unknown & TC48313 & 0.26 & 0.60 & 0.22 & 0.18 \\
\hline MT001354 & Unknown & TC44828 & 0.22 & 0.75 & -0.16 & -0.01 \\
\hline
\end{tabular}

${ }^{\text {a }}$ Expression ratio is expressed in $\log _{2}$. Values greater than $0.58\left(\log _{2} 1.5\right)$ are in bold. dpi = days postinoculation. 
The two NIL (210A and 210F) were selected among heterogeneous inbred families, generated following self-fertilization of the no. 210 F7 LR5 (A17 $\times$ F83005.5) RIL that is heterozygous for the entire $C t 1$ region. Five simple-sequence repeat markers (mtic331, h2_8d13, mtCt12, mtCt14, and mtic510) designed from $\mathrm{BAC}$ sequences covering the $\mathrm{Ct} 1$ region (Ameline-Torregrosa et al. 2008) were used to select $210 \mathrm{~A}$ and $210 \mathrm{~F}$ that differed by the A17 or F83005.5 alleles throughout the $\mathrm{Ct} 1$ locus.

Table 4. Genes belonging to group III, mainly downregulated in the Medicago truncatula lines inoculated with Colletotrichum spp. at 3 dpi ${ }^{\text {a }}$

\begin{tabular}{|c|c|c|c|c|c|c|}
\hline \multirow[b]{2}{*}{ Mt16kOLIplus } & \multirow[b]{2}{*}{ Annotation } & \multirow[b]{2}{*}{ TIGR v5 } & \multicolumn{2}{|c|}{ 210A } & \multicolumn{2}{|c|}{$210 \mathrm{~F}$} \\
\hline & & & Nonhost & Host & Nonhost & Host \\
\hline \multicolumn{7}{|c|}{ Signaling/transcription } \\
\hline MT010852 & Mitogen-activated protein kinase & TC55662 & -1.03 & -0.79 & 0.16 & -0.11 \\
\hline МТ004670 & Serine/threonine protein kinase & TC48472 & -0.98 & -0.96 & -0.06 & -0.04 \\
\hline МT009563 & Tyrosine protein kinase & TC54253 & -0.10 & -0.62 & -0.22 & -0.12 \\
\hline МТ015899 & Protein kinase & TC56690 & -0.15 & -0.32 & -0.25 & $-\mathbf{0 . 5 9}$ \\
\hline MT012179 & Protein kinase & TC57109 & -0.07 & -0.07 & -0.18 & -0.87 \\
\hline МТ006189 & Phosphatase 2C HAB1 & TC50097 & -0.58 & -0.59 & -0.14 & 0.01 \\
\hline MT006956 & Phosphatidylinositol phosphatase, SAC9 & TC50939 & -1.47 & -1.55 & 0.00 & -0.04 \\
\hline MT001262 & Regulatory protein NPR3-like & TC44718 & -0.88 & -0.86 & -0.16 & 0.00 \\
\hline MT016089 & SAR DNA-binding protein & & -0.30 & -0.61 & -0.18 & -0.04 \\
\hline MT011639 & RNA-binding protein & TC56510 & -0.17 & -0.75 & -0.16 & -0.19 \\
\hline MT000562 & CID4 protein binding & TC43872 & -0.76 & -0.74 & -0.06 & -0.19 \\
\hline MT015771 & Nucleic-binding protein & TC55006 & -0.67 & -0.27 & 0.23 & 0.00 \\
\hline MT016282 & MYB transcription factor & BI266990 & -0.18 & -0.59 & 0.02 & -0.14 \\
\hline MT011522 & Zinc finger protein (CCCH type ) & TC56387 & -0.09 & -0.41 & -0.11 & -0.62 \\
\hline MT011335 & GRAS family transcription factor & TC56187 & 0.254 & 0.941 & -0.19 & $-\mathbf{0 . 5 9}$ \\
\hline MT003059 & Protein transport factor & TC46716 & 0.07 & 0.02 & -0.54 & -0.75 \\
\hline MT001108 & F-box family protein & TC44539 & -0.34 & -0.60 & -0.32 & -0.27 \\
\hline MT002615 & Ubiquitin, DNA-damage inducible & TC46226 & -0.17 & -0.61 & -0.14 & -0.21 \\
\hline MT013464 & Ubiquitin-associated protein & TC58492 & -0.53 & -0.65 & 0.00 & -0.09 \\
\hline MT001795 & Endonuclease & TC45314 & -0.16 & -0.24 & -0.29 & -0.62 \\
\hline MT014949 & Tetratricopeptide-like helical & TC49771 & -0.20 & -0.69 & 0.29 & 0.04 \\
\hline MT007217 & Ribosomal protein L5 & TC51442 & -0.11 & -0.63 & 0.01 & 0.13 \\
\hline MT011937 & 60S ribosomal protein L5 & TC56837 & -0.67 & -0.93 & -0.11 & 0.00 \\
\hline MT012504 & Translation elongation factor & TC57461 & -0.64 & -0.42 & 0.21 & -0.02 \\
\hline \multicolumn{7}{|l|}{ Defense } \\
\hline MT007395 & Pectate lyase & TC51696 & -0.07 & -0.59 & 0.13 & -0.02 \\
\hline MT000827 & Trypsin/chymotrypsin inhibitor & TC44197 & -0.13 & 0.211 & -0.64 & -0.62 \\
\hline \multicolumn{7}{|c|}{ Secondary metabolism } \\
\hline MT014003 & 3-Hydroxy-3-methylglutaryl coA reductase & TC43337 & -0.17 & -0.43 & -0.15 & -0.60 \\
\hline \multicolumn{7}{|c|}{ Primary metabolism } \\
\hline MT014115 & Chlorophyll a-b binding protein & TC42999 & -0.31 & -0.58 & -0.28 & -0.82 \\
\hline MT015098 & Chlorophyll a-b binding protein & TC51045 & -0.30 & -0.55 & -0.22 & $-\mathbf{0 . 7 0}$ \\
\hline MT015099 & Chlorophyll $\mathrm{a}-\mathrm{b}$ binding protein & TC51048 & -0.28 & $-\mathbf{0 . 5 8}$ & -0.21 & -0.69 \\
\hline MT007170 & Chlorophyll $\mathrm{a}-\mathrm{b}$ binding protein & TC51376 & -0.30 & -0.53 & -0.18 & -0.64 \\
\hline MT014000 & Chlorophyll $\mathrm{a}-\mathrm{b}$ binding protein & TC43260 & -0.24 & -0.37 & -0.16 & -0.61 \\
\hline MT007180 & Chlorophyll a-b binding protein & TC51387 & -0.25 & -0.22 & -0.12 & -0.60 \\
\hline MT014110 & Chlorophyll a-b binding protein & TC43015 & -0.21 & -0.57 & -0.21 & -0.59 \\
\hline MT000102 & Light harvesting chlorophyll binding protein & TC43184 & -0.16 & -0.58 & -0.24 & $-\mathbf{0 . 8 0}$ \\
\hline MT007374 & Photosystem reaction center subunit III & TC51661 & -0.33 & -0.52 & -0.17 & -0.64 \\
\hline MT003736 & Photosystem I apoprotein A2 & TC47460 & -0.36 & -0.85 & -0.35 & -0.43 \\
\hline MT003797 & Photosystem I apoprotein A2 & TC47528 & -0.29 & -0.97 & -0.34 & -0.57 \\
\hline MT015090 & Cytochrome b & TC51032 & -0.36 & -0.64 & -0.17 & -0.29 \\
\hline MT007914 & Phosphoenolpyruvate carboxylase & TC52360 & -0.14 & -0.64 & -0.20 & -0.45 \\
\hline MT000004 & RuBisco activator & TC42987 & -0.26 & -0.69 & -0.15 & -0.37 \\
\hline MT014109 & RuBisco small chain & TC43011 & -0.20 & -0.53 & -0.25 & -0.66 \\
\hline MT014122 & RuBisco small chain & TC43011 & -0.17 & -0.50 & -0.23 & -0.61 \\
\hline MT014158 & RuBisco small chain & TC43108 & -0.25 & -0.53 & -0.27 & -0.61 \\
\hline MT014123 & RuBisco small chain & TC43044 & -0.24 & -0.47 & -0.26 & -0.60 \\
\hline MT015214 & Glyceraldehyde 3 phosphate dehydrogenase & TC51277 & -0.14 & -0.55 & -0.17 & -0.63 \\
\hline MT011509 & Glycosyl hydrolase & TC56373 & -0.18 & -0.66 & -0.14 & -0.29 \\
\hline MT000153 & $\beta$-Glucosidase & TC43298 & -0.27 & -0.46 & -0.27 & $-\mathbf{0 . 5 9}$ \\
\hline MT008500 & Nudix hydrolase & TC53066 & -1.11 & -0.93 & 0.03 & 0.00 \\
\hline \multicolumn{7}{|c|}{ Unclassed/unknown } \\
\hline MT000479 & Unknown & TC43763 & -0.15 & -0.64 & -0.04 & -0.12 \\
\hline MT001113 & Unknown & TC44544 & -0.22 & -0.59 & -0.24 & -0.21 \\
\hline MT012125 & Unknown & TC57053 & -0.21 & -0.67 & 0.15 & 0.03 \\
\hline MT013579 & Unknown & TC58616 & -0.29 & -0.62 & -0.16 & -0.23 \\
\hline MT014544 & Unknown & TC44796 & -0.33 & -0.63 & -0.07 & -0.10 \\
\hline MT015334 & Unknown & TC51669 & -0.34 & -0.69 & -0.39 & -0.37 \\
\hline MT015335 & Unknown & TC51670 & -0.32 & -0.73 & -0.24 & -0.24 \\
\hline MT012317 & Unknown & TC57260 & -1.35 & -1.41 & 0.12 & -0.01 \\
\hline MT005834 & Unknown & TC49714 & -0.85 & -0.95 & -0.02 & 0.24 \\
\hline MT004344 & Unknown & TC48120 & -0.62 & -0.72 & -0.20 & 0.00 \\
\hline MT000372 & Unknown & TC43634 & -0.62 & -0.64 & -0.02 & 0.08 \\
\hline MT008209 & Unknown & ТС52709 & 0.02 & -0.07 & -0.84 & -0.78 \\
\hline
\end{tabular}

\footnotetext{
${ }^{\text {a }}$ Values lower than $-0.58\left(\log _{2} 0.67\right)$ are in bold. $\mathrm{dpi}=$ days postinoculation.
} 
Plants seed were surface sterilized for 5 min in sulfuric acid, rinsed several times with sterile water, and germinated on $1 \%$ agar plates for 2 days at $20^{\circ} \mathrm{C}$ in the dark after 1 night at $4^{\circ} \mathrm{C}$. Seedlings were transferred to soil and cultivated in a growth chamber with a regime of $16 \mathrm{~h}$ of light at $25^{\circ} \mathrm{C}$ and $8 \mathrm{~h}$ of darkness at $22^{\circ} \mathrm{C}$.

\section{Inoculation procedures.}

C. trifolii Bain race 2 (Ameline-Torregrosa et al. 2008), $C$. lindemuthianum (Sacc. et Magn.) Briosi and Cav. race $\beta$ (Wong Sak Hoi et al. 2007), C. higginsianum IMI349063 (O'Connell et al. 2004), and a C. lindemuthianum CLSTE12 mutant (Wong Sak Hoi et al. 2007) were used. Conidia were produced after 7 days at $23^{\circ} \mathrm{C}$ on the medium described by (Bannerot 1965). Spores were collected in sterile water and the concentration was adjusted to $10^{6}$ cells $/ \mathrm{ml}$ in $0.01 \%$ Tween 20 (Sigma-Aldrich, St. Louis). Inoculations were done on detached leaves or on 2-week-old intact plant as described (Torregrosa et al. 2004). The experiments were repeated at least three times independently. Symptoms were observed at 3 or 7 dpi.

\section{Microscopic analyses.}

Accumulation of autofluorescent compounds in the inoculated leaves was followed by epifluorescence microscopy, using an inverted microscope (Leitz DM IRBE, Leica, Germany) with excitation filter BP (340 to $380 \mathrm{~nm}$ ) and barrier filter LP $(425 \mathrm{~nm})$. Images were recorded with the same settings using a CCD color digital camera (Photonic Science, Robertsbridge, East Sussex, U.K.).

\section{qRT-PCR.}

Total RNA was extracted from $100 \mathrm{mg}$ of shock-frozen leaves using the Qiagen RNeasy plant mini kit RNA cleanup protocol. RNA quality was checked using the Agilent 2100 Bioanalyzer. cDNAs were synthesized from $2 \mu \mathrm{g}$ of total RNA using the SuperScript III kit (Invitrogen, Carlsbad, CA, U.S.A.) with OligodT primers. Real-time qRT-PCR was performed on an ABI Prism SDS 7900HT (Applied Biosystems, Foster City, CA, U.S.A.). Each 10- $\mu$ l PCR reaction contained $2 \mu$ of a 1:50 dilution of the synthesized cDNA, $5 \mu$ l of SYBR Green $2 \times$ (Invitrogen), and primers $(0.15 \mu \mathrm{M}$ each). The PCR program consisted of 5 min of incubation at $95^{\circ} \mathrm{C}$ followed by 40 cycles of $15 \mathrm{~s}$ at $95^{\circ} \mathrm{C}$ and $30 \mathrm{~s}$ at $60^{\circ} \mathrm{C}$. qPCR reactions were performed in triplicate for each of three biological replications. Data analysis and calculations for comparing expression data were performed using the $\Delta \Delta$ cycle threshold method with the elongation factor EF1 $\alpha$ as the constitutively expressed gene. PCR efficiency was evaluated by performing qPCR on serial dilutions of a mixture of all cDNAs. Amplification specificity for each gene was confirmed by a single dissociation curve peak generated at the end of the PCR cycle. The following primer sequences were used: TC111470 (EF1 $\alpha)$, forward, 5'GACAAGCGTGTGATCGAGAGATT-3', reverse, 5'-TTTCA CGCTCAGCCTTAAGCT-3'; Y08641 (PR10-1), forward, 5' TGGAAAAGCTAGGGGTGATG-3', reverse, 5'-CCGTCTAT AAAGCAAGCAAGC-3'; AJ277211.1 (CHS1), forward, 5'TTGCGCAGTGTCGCTATATG-3', reverse, 5'-TGAGGGTA CATGTTGAACACTAGA-3'; TC53754 (transcription factor, CCCH-type), forward, 5'-AGGCTCCTCCAACAGTAGCA3', reverse, 5'-GCAGCCTGAATCTTGGACTC-3'; TC48442, (RING-finger protein) forward, 5'-GAAGGGACTGGTGC AAATGT-3', reverse, 5'-TGGGACGATAAAGGAGATGC-3'; TC47188 (adenylate kinase), forward, 5'-TGTCCAGAAAC GTGCAGAAG-3', reverse, 5'-ATAATGCCGAGGAGTGATC G-3'; TC43082 (hydroxyproline-rich glycoprotein), forward, 5'-TCTTACCTTGCGATCCCAAA-3', reverse, 5'-GTGGTGG GGAACTGTAATGG-3'; and TC43281, (isoflavone reductase), forward, 5'-GAATTTGGGCTAGACGTGGA-3', reverse, 5'-T ATCCCGAGGAGGATCAGTG-3'.

\section{Microarrays.}

Total RNA from ground leaves was extracted using TRIzol reagent (Invitrogen) and purified using Microcon-30 columns (Millipore, Billerica, MA, U.S.A.). Total RNA (5 $\mu \mathrm{g}$ of each sample) was used to synthesize Cy3-labeled cDNA targets using a mixture of $2 \mu \mathrm{g}$ of double anchored oligo(dT) $15 \mathrm{VN}$ primers and $3 \mu \mathrm{g}$ of random primers with the CyScribe firststrand cDNA labeling Kit (GE Healthcare Europe, Orsay, France). Total RNA of each sample was similarly labeled with the Cy5 dye. Labeled cDNA was purified using the ChipShot Membrane Clean Up System (Promega Corp, Madison, WI, U.S.A.), and labeling efficiency was checked by measuring absorbance at 260,550, and $650 \mathrm{~nm}$ with a Nanodrop (Thermo Scientific, Waltham, MA, U.S.A.). Only labeled cDNA having a frequency of incorporation of at least 20 labeled nucleotides per thousand was used for hybridization. Microarray analyses were performed using Mt16kOLI1Plus chips representing all 16,086 tentative consensus sequences of the TIGR $M$. truncatula Gene Index 5, plus a set of 384 oligonucleotides representing transcription factors and regulators. Automatic hybridization of a mix containing the same quantity of $\mathrm{Cy} 3$ and Cy5-labeled cDNA was performed using a Ventana's Discovery System (Ventana, Illkirch, France) following the standard procedure. After $16 \mathrm{~h}$ of hybridization at $42^{\circ} \mathrm{C}$, microarrays slides were washed twice in RiboWash reagent (1 $\left.\min , 20^{\circ} \mathrm{C}\right)$ and once in $0.1 \times \mathrm{SSC}\left(1 \mathrm{~min}, 20^{\circ} \mathrm{C}\right)(1 \times \mathrm{SSC}$ is $0.15 \mathrm{M} \mathrm{NaCl}$ plus $0.015 \mathrm{M}$ sodium citrate). Slides were dried by centrifugation $\left(185 \times g, 5 \mathrm{~min}, 20^{\circ} \mathrm{C}\right)$ and scanned using the Genepix 4000 scanner (Axon Instruments, Sunnyvale, CA, U.S.A.). Image processing was performed using the Mapix software (Innopsys, Carbonne, France). Data analysis was done using MAnGO on the R software (Marisa et al. 2007).

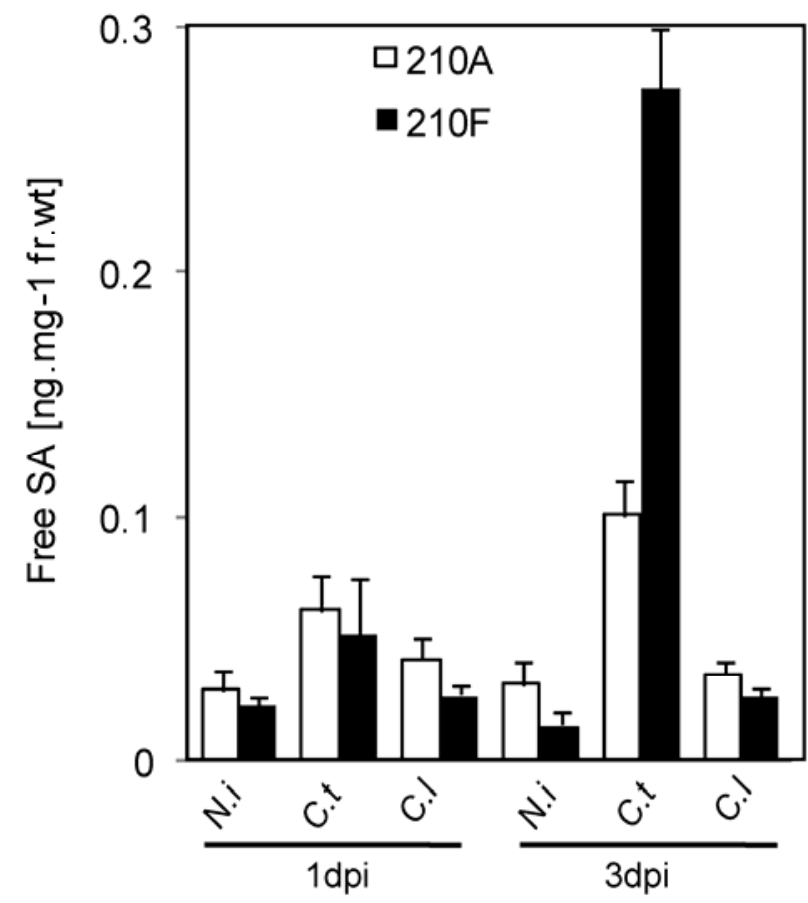

Fig. 7. Salicylic acid (SA) quantification in Medicago truncatula lines inoculated with Colletotrichum spp. Aerial parts of 2-week-old M. truncatula plants $(210 \mathrm{~A}$ or $210 \mathrm{~F})$ were inoculated by spraying a conidial suspension of Colletotrichum lindemuthianum or C. trifolii. Free SA was quantified at 1 or 3 days postinoculation according to a protocol adapted from Forcat and associates (2008). 
An intraslide normalization was performed using Loess on each array without background correction, follow by a Rquantile interslide normalization. All data were deposited in MIAME compliant format into the ArrayExpress database under accession no. E-MEXP-2349. After ANOVA analysis, a gene was considered responsive to the treatments if it associated with a $P$ value $\leq 0.05$ and differentially expressed if the absolute value of $\log _{2}$ ratio was $\geq 0.584$ ( $>1.5$ fold induction or $<0.67$ repression). Hierarchical clustering of all genes marked as differentially expressed in one condition at least was performed using the HCE3.5 software with the complete linkage method and the Manhattan distance measure.

\section{SA measurements.}

SA was quantified in leaf tissues of entire plants inoculated with the different fungi in three biological replicates. Free SA was extracted and measured in $M$. truncatula leaf tissues according to a protocol adapted from Forcat and associates (2008). Briefly, the methanolic supernatant containing free SA and its internal standard, ${ }^{2} \mathrm{H}_{4}$-SA, was analyzed by ultra-performance liquid chromatographic (UPLC)-electrospray tandem mass spectrometry using an Acquity UPLC coupled to a Micromass Q-Tof Premier (Waters, Milford, MA, U.S.A.) orthogonal acceleration time-of-flight mass spectrometer. Chromatographic separations were performed on an Acquity UPLC BEH C18 analytical column (100 $\mathrm{mm}$ by $2.1 \mathrm{~mm}$ by $1.7 \mu \mathrm{m})$ (Waters). The binary solvent system included $\mathrm{A}=$ water $+0.1 \%$ $\mathrm{HCOOH}$ and $\mathrm{B}=$ acetonitrile (liquid chromatography-mass spectrometry grade). The gradient profile consisted of 0 to 1 min, $5 \% \mathrm{~B} ; 1$ to $8 \mathrm{~min}, 5$ to $68 \% \mathrm{~B} ; 8$ to $9 \mathrm{~min}, 95 \% \mathrm{~B} ; 9$ to 10 $\min , 95 \% \mathrm{~B} ; 10$ to $11 \mathrm{~min}, 5 \% \mathrm{~B}$; and 11 to 12 , min $5 \% \mathrm{~B}$ with a flow rate of $300 \mu \mathrm{l} / \mathrm{min}$. The mass spectrometry was operated in the negative mode. Quantification was based on pseudomultiple reaction monitoring after collision-induced dissociation at $15 \mathrm{eV}$ using the following mass transition: $137.0>93.0$ for SA and $141.0>97.0$ for ${ }^{2} \mathrm{H}_{4}$-SA. Concentration of free SA in the sample was determined in relation to the ${ }^{2} \mathrm{H}_{4}-\mathrm{SA}$ internal standard using QuanLynx software (Waters).

\section{ACKNOWLEDGMENTS}

This research was supported in part by Groupe Roullier (France) and by an ANRT Ph.D. fellowship to V. Jaulneau. We thank J. M. Prosperi for supplying seed of Medicago truncatula, X. Briand and S. Salamagne (Groupe Roullier, France) for helpful discussions, the "Genopole Toulouse Midi-Pyrénées" for access to the "Genotyping and Sequencing" and "Biochips" platforms, and Y. Lippi (UMR 5546 CNRS-UPS) for help in microarray data analyses.

\section{LITERATURE CITED}

Abramovitch, R. B., Kim, Y. J., Chen, S. R., Dickman, M. B., and Martin, G. B. 2003. Pseudomonas type III effector AvrPtoB induces plant disease susceptibility by inhibition of host programmed cell death. EMBO (Eur. Mol. Biol. Organ.) J. 22:60-69.

Ameline-Torregrosa, C., Cazaux, M., Danesh, D., Chardon, F., Cannon, S. B., Esquerre-Tugaye, M. T., Dumas, B., Young, N. D., Samac, D. A., Huguet, T., and Jacquet, C. 2008. Genetic dissection of resistance to anthracnose and powdery mildew in Medicago truncatula. Mol. PlantMicrobe Interact. 21:61-69.

Assaad, F. F., Qiu, J. L., Youngs, H., Ehrhardt, D., Zimmerli, L., Kalde, M., Wanner, G., Peck, S. C., Edwards, H., Ramonell, K., Somerville, C. R., and Thordal-Christensen, H. 2004. The PEN1 syntaxin defines a novel cellular compartment upon fungal attack and is required for the timely assembly of papillae. Mol. Biol. Cell 15:5118-5129.

Bannerot, H. 1965. Résultats d'infection d'une collection de haricot par six races physiologiques d'anthracnose. Ann. Amélior. Plant. 15:210222.

Boller, T., and Felix, G. 2009. A renaissance of elicitors: Perception of microbe-associated molecular patterns and danger signals by patternrecognition receptors. Annu. Rev. Plant Biol. 60:379-406.
Bonanomi, A., Oetiker, J. H., Guggenheim, R., Boller, T., Wiemken, A., and Vogeli-Lange, R. 2001. Arbuscular mycorrhiza in mini-mycorrhizotrons: First contact of Medicago truncatula roots with Glomus intraradices induces chalcone synthase. New Phytol. 150:573-582.

Bos, J. I., Chaparro-Garcia, A., Quesada-Ocampo, L. M., McSpadden Gardener, B. B., and Kamoun, S. 2009. Distinct amino acids of the Phytophthora infestans effector AVR3a condition activation of R3a hypersensitivity and suppression of cell death. Mol. Plant-Microbe Interact. 22:269-281.

Boudart, G., Charpentier, M., Lafitte, C., Martinez, Y., Jauneau, A., Gaulin, E., Esquerre-Tugaye, M. T., and Dumas, B. 2003. Elicitor activity of a fungal endopolygalacturonase in tobacco requires a functional catalytic site and cell wall localization. Plant Physiol. 131:93-101.

Deng, F., Allen, T. D., and Nuss, D. L. 2007. Ste12 transcription factor homologue $\mathrm{CpST} 12$ is down-regulated by hypovirus infection and required for virulence and female fertility of the chestnut blight fungus Cryphonectria parasitica. Eukaryot. Cell 6:235-244.

Dou, D., Kale, S. D., Wang, X., Chen, Y., Wang, Q., Jiang, R. H., Arredondo, F. D., Anderson, R. G., Thakur, P. B., McDowell, J. M., Wang, Y., and Tyler, B. M. 2008. Conserved C-terminal motifs required for avirulence and suppression of cell death by Phytophthora sojae effector Avr1b. Plant Cell 20:1118-1133.

Faivre-Rampant, O., Thomas, J., Allegre, M., Morel, J. B., Tharreau, D. Notteghem, J. L., Lebrun, M. H., Schaffrath, U., and Piffanelli, P. 2008. Characterization of the model system rice-Magnaporthe for the study of nonhost resistance in cereals. New Phytol. 180:899-910.

Forcat, S., Bennett, M. H., Mansfield, J. W., and Grant, M. R. 2008. A rapid and robust method for simultaneously measuring changes in the phytohormones ABA, JA and SA in plants following biotic and abiotic stress. Plant Methods 4:16.

Gamas, P., de Billy, F., and Truchet, G. 1998. Symbiosis-specific expression of two Medicago truncatula nodulin genes, MtN1 and MtN13, encoding products homologous to plant defense proteins. Mol. PlantMicrobe Interact. 11:393-403.

Geffroy, V., Sevignac, M., Billant, P., Dron, M., and Langin, T. 2008. Resistance to Colletotrichum lindemuthianum in Phaseolus vulgaris: A case study for mapping two independent genes. Theor. Appl. Genet. 116:407-415.

Hein, I., Gilroy, E. M., Armstrong, M. R., and Birch, P. R. J. 2009. The zig-zag-zig in oomycete-plant interactions. Mol. Plant Pathol. 10:547562.

Herbert, C., Jacquet, C., Borel, C., Esquerre-Tugaye, M. T., and Dumas, B. 2002. A cis-acting sequence homologous to the yeast filamentation and invasion response element regulates expression of a pectinase gene from the bean pathogen Colletotrichum lindemuthianum. J. Biol. Chem. 277:29125-29131.

Lipka, U., Fuchs, R., and Lipka, V. 2008. Arabidopsis non-host resistance to powdery mildews. Curr. Opin. Plant Biol. 11:404-411.

Marisa, L., Ichante, J. L., Reymond, N., Aggerbeck, L., Delacroix, H., and Mucchielli-Giorgi, M. H. 2007. MAnGO: An interactive R-based tool for two-colour microarray analysis. Bioinformatics 23:2339-2341.

Mysore, K. S., and Ryu, C. M. 2004. Nonhost resistance: How much do we know? Trends Plant Sci. 9:97-104.

Nurnberger, T., and Lipka, V. 2005. Non-host resistance in plants: New insights into an old phenomenon. Mol. Plant Pathol. 6:335-345.

O'Connell, R., Herbert, C., Sreenivasaprasad, S., Khatib, M., EsquerreTugaye, M. T., and Dumas, B. 2004. A novel Arabidopsis-Colletotrichum pathosystem for the molecular dissection of plant-fungal interactions. Mol. Plant-Microbe Interact. 17:272-282.

Park, G., Xue, C., Zheng, L., Lam, S., and Xu, J. R. 2002. MST12 regulates infectious growth but not appressorium formation in the rice blast fungus Magnaporthe grisea. Mol. Plant-Microbe Interact. 15:183-192.

Shimada, C., Lipka, V., O'Connel, R., Okuno, T., Schulze-Lefert, P., and Takano, Y. 2006. Nonhost resistance in Arabidopsis-Colletotrichum interactions acts at the cell periphery and requires actin filament function. Mol. Plant-Microbe Interact. 19:270-279.

Tao, Y., Xie, Z., Chen, W., Glazebrook, J., Chang, H. S., Han, B., Zhu, T. Zou, G, and Katagiri, F. 2003. Quantitative nature of Arabidopsis responses during compatible and incompatible interactions with the bacterial pathogen Pseudomonas syringae. Plant Cell 15:317-330.

Thompson, R., Ratet, P., and Küster, H. 2005. Identification of gene functions by applying TILLING and insertional mutagenesis strategies on microarray-based expression data. Grain Legumes 41:20-22.

Thordal-Christensen, H. 2003. Fresh insights into processes of nonhost resistance. Curr. Opin. Plant Biol. 6:351-357.

Torregrosa, C., Cluzet, S., Fournier, J., Huguet, T., Gamas, P., Prosperi, J. M., Esquerre-Tugaye, M. T., Dumas, B., and Jacquet, C. 2004. Cytological, genetic, and molecular analysis to characterize compatible and incompatible interactions between Medicago truncatula and Colletotrichum trifolii. Mol. Plant-Microbe Interact. 17:909-920. 
Uppalapati, S. R., Toyoda, K., Yasuhiro, I., Ichinose, Y., and Shiraishi, T. 2004. Differential regulation of MBP kinases by a glycoproptein elicitor and a polypeptide suppressor from Mycosphaerella pinodes in pea. Physiol. Mol. Plant Pathol. 64:17-25.

Veneault-Fourrey, C., Lauge, R., and Langin, T. 2005. Nonpathogenic strains of Colletotrichum lindemuthianum trigger progressive bean defense responses during appressorium-mediated penetration. Appl. Environ. Microbiol. 71:4761-4770.

Williams, M. E., Torabinejad, J., Cohick, E., Parker, K., Drake, E. J., Thompson, J. E., Hortter, M., and DeWald, D. B. 2005. Mutations in the Arabidopsis phosphoinositide phosphatase gene SAC9 lead to overaccumulation of PtdIns(4,5)P-2 and constitutive expression of the stress-response pathway. Plant Physiol. 138:686-700.

Wong Sak Hoi, J., Herbert, C., Bacha, N., O’Connell, R., Lafitte, C., Borderies, G., Rossignol, M., Rougé, P., and Dumas, B. 2007. Regulation and role of a STE12-like transcription factor from the plant pathogen Colletotrichum lindemuthianum. Mol. Microbiol. 64:68-82.

Yang, S., Gao, M., Xu, C., Gao, J., Deshpande, S., Lin, S., Roe, B. A., and Zhu, H. 2008. Alfalfa benefits from Medicago truncatula: The RCT1 gene from $M$. truncatula confers broad-spectrum resistance to anthracnose in alfalfa. Proc. Natl. Acad. Sci. U.S.A. 105:1216412169.
Yang, S. L., and Chung, K. R. 2010. Transcriptional regulation of elsinochrome phytotoxin biosynthesis by an EfSTE12 activator in the citrus scab pathogen Elsinoe fawcettii. Fungal Biol. 114:64-73.

Zhang, Y. L., Cheng, Y. T., Qu, N., Zhao, Q. G., Bi, D. L., and Li, X. 2006 Negative regulation of defense responses in Arabidopsis by two NPR1 paralogs. Plant J. 48:647-656.

Zimmerli, L., Stein, M., Lipka, V., Schulze-Lefert, P., and Somerville, S. 2004. Host and non-host pathogens elicit different jasmonate/ethylene responses in Arabidopsis. Plant J. 40:633-646.

Zipfel, C. 2008. Pattern-recognition receptors in plant innate immunity. Curr. Opin. Immunol. 20:10-16.

\section{AUTHOR-RECOMMENDED INTERNET RESOURCES}

Colletotrichum.org, a website for the Colletotrichum research community: www.colletotrichum.org

INRA and CNRS Legoo database, a bioinformatics gateway towards integrative legume biology: www.legoo.org/

The Medicago truncatula sequencing project: www.medicago.org/genome University of Maryland's Human-Computer Interaction Lab Hierarchical Clustering Explorer vs. 3.5 software: www.cs.umd.edu/hcil/hce 